\title{
Taq Man Real Time PCR detection of Listeria monocytogenes: a study of enrichment incubation time affecting sensitivity in experimental dry fermented
} sausages

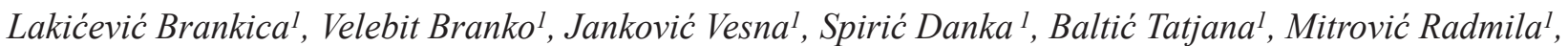 \\ Babić Jelena ${ }^{1}$
}

A b s t r a c t: Listeria monocytogenes is a facultative intracellular Gram positive, catalase positive bacterium, ubiquitous in nature and capable of causing listeriosis in humans and animals. Conventional microbiological techniques and modern molecular approaches are currently used for the isolation and detection of Listeria monocytogenes in food samples. The aim of this study was to investigate the influence of enrichment incubation time on the sensitivity of Taq Man Real Time PCR method. For that purpose, dry fermented sausages were artificially inoculated with serial dilutions of L. monocytogenes ATCC 19111. The obtained results indicated that incubation time is an important factor affecting the sensitivity of Real-Time PCR detection. The best results were obtained after $24 \mathrm{~h}$ of pre-enrichment, with primers and probe complementary to the listeriolysin (hlyA) gene, when it was possible to detect less than 10 CFU/g of L. monocytogenes.

Key words: detection, L. monocytogenes, Real-Time PCR, sensitivity, DNA extraction.

\section{Introduction}

Listeria monocytogenes, an opportunistic bacteria, is recognized worldwide as one of the most important foodborne pathogens of concern for the food industries. Listeria monocytogenes is a ubiquitous microorganism and it is commonly isolated from foods of animal origin, mainly meat and milk products (Schuchat et al., 1991), but it can also be found in fresh products, such as salads (Berrada et al., 2006). However, human listeriosis outbreaks are most often associated with ready-to-eat food that is consumed without prior cooking (Ryser, 1999). Ingestion of foods contaminated with L. monocytogenes can result in listeriosis, a severe infectious disease characterized by meningoencephalitis, abortion, septicemia, and a high fatality rate (30\%). Listeriosis predominantly affects certain risk groups, including neonates, young children, seniors over the age of 65 , pregnant women, or people with compromised immune systems (Kathariou, 2002; McLauchlin et al., 2004). The main route of transmission of L. monocytogenes to humans is the consumption of contaminated minimally processed food
(Schlech, 2000; Kathariou, 2002; Shen et al., 2006). However, other modes of transmission can occur, including transplancental mother-to-child transmission. Several large outbreaks of listeriosis have been associated with contaminated commercial foodstuffs, such as vegetables, milk and meat products, in which these bacteria can multiply even at low temperatures (Schuchat et al., 1991). Usually, the presence of any Listeria species in food is an indicator of poor hygiene (McLaughlin, 1997). Increased public awareness of the health-related and economic impacts of food contamination and foodborne illnesses has resulted in greater efforts to develop sensitive methods for pathogen detection and identification (Lakicevic et al., 2011). The specific identification of L. monocytogenes, based on culture and biochemical methods, is laborious and time consuming, and according to the International Organization for Standardization, requires up to a week for species identification in food products (ISO 11290-2, Anon. 1998). Culture methods have also been reported to show poor sensitivity for low-level contamination in samples (D'Aoust, 1992).

${ }^{1}$ Institute of Meat Hygiene and Tehnology, Kaćanskog 13, Belgrade, Republic of Serbia.

Corresponding author: Lakićević Brankica, brankica@inmesbgd.com 
Therefore, the food industry needs faster techniques to trace sources of contamination and assess whether cleaning procedures are adequate. Recent developments in molecular diagnostics of L. monocytogenes include rapid, accurate and reliable methods for the detection of low concentrations of $L$. monocytogenes from a variety of food and environmental samples (Aznar and Alarcón, 2003; Cocolin et al., 2002; Kaur et al., 2007). Also, molecular techniques allow the identification of the cultivable and non-cultivable fraction of microorganisms present in one sample. The aim of this work was to investigate the influence of enrichment incubation time on the sensitivity of the method.

\section{Materials and methods}

\section{Preparation of sausages}

The traditional dry fermented sausages were manufactured from a mixture of lean minced pork $(80 \%)$ and pig fat $(20 \%)$ obtained from carcasses of Large White crossbreed animals. After grinding the meat and the fat to the size of about $10 \mathrm{~mm}$ (with adjustable plate holder diameter set), raw materials were mixed with seasonings $(2.50 \%$ red hot paprika powder, $1.80 \%$ salt, $0.20 \%$ raw garlic paste, $0.20 \%$ caraway and $0.15 \%$ sucrose) for about $10 \mathrm{~min}$. A well-mixed filling, which was prepared within 15-30 minutes by using a unique technique of manual mixing with kneading and overturning, was stuffed into natural casings consisting of the rear part of pig intestines (rectum), and afterwards sausage units of 35$45 \mathrm{~cm}$ long and $4.5-5.0 \mathrm{~cm}$ in diameter were shaped. The sausages were left to drain for a while and then they were periodically cold smoked for about 10-15 days, using specific kinds of wood (cherry wood, in particular). When the smoking process was finished, the sausages were kept in a dry and well ventilated place to dry and ripen, until an optimum quality was achieved, which lasted for about four months.

\section{Bacterial strain and growth conditions}

The standard strain of Listeria monocytogenes ATCC 19111 was obtained from The American Type Culture Collection (ATCC; Manassas, Va., USA). Standard strain was grown on brain-heart agar (BHA), (Merck, GmbH Darmstadt, Germany), at $37^{\circ} \mathrm{C}$, during $24 \mathrm{~h}$. Fraser broth (Merck) was used for the enrichment step.

\section{Sample preparation for sensitivity assay}

Sensitivity assays were carried out on artificially inoculated samples prepared as follows: 40 $\mathrm{g}$ of dry fermented sausage, previously cut into ca. $2 \mathrm{~g}$ pieces, were added to $360 \mathrm{~mL}$ of half-concentrated Fraser broth (half content of selective components, as recommended by the manufacturer) in a sterile plastic bag with lateral filter, and homogenized in a stomacher (MIX 2, AES Chemunex, France) for $1 \mathrm{~min}$. The resulting mixture was distributed in $40 \mathrm{~mL}$ aliquots, and inoculated with $400 \mu \mathrm{L}$ of 10 -fold serial dilutions of standard $L$. monocytogenes ATCC 19111 strain in sterile saline $(0.9 \% \mathrm{NaCl})$, covering the range from 1 to $1 \times 10^{7} \mathrm{CFU} \mathrm{mL} \mathrm{mL}^{-1}$ (determined by plate count on BHA). The negative control contained no inoculum. Afterwards, samples were incubated at $37^{\circ} \mathrm{C}$, and ten millilitre aliquots were used for DNA extraction at 0,2 and $6 \mathrm{~h}$ of incubation, and $1 \mathrm{~mL}$ aliquots after $24 \mathrm{~h}$ incubation.

\section{DNA extraction}

Two methods for DNA extraction from dry fermented sausages were evaluated. One method was based on DNA purification through chromatography columns (DNeasy Tissue Kit, Qiagen $\mathrm{GmbH}$, Germany), according to the manufacturer's protocol for Gram positive bacteria, and the other one was heat treatment-based method by using PrepMan ${ }^{\circledR}$ Ultra Sample Preparation Reagent (Applied Biosystems, USA).

Table 1. The oligonucleotides used for Real Time PCR detection of Listeria monocytogenes

Tabela 1. Oligonukleotidi korišćeni za Real Time PCR detekciju Listeria monocytogenes

\begin{tabular}{|c|c|c|}
\hline Primer and probe sequence orientation $\mathbf{5}^{\prime} \rightarrow \mathbf{3}^{\prime}$ & Target gene & PCR product \\
\cline { 1 - 2 } hlyQF: 5'- CATGGCACCACCAGCATCT -3' & \multirow{2}{*}{ hly } & $64 \mathrm{bp}$ \\
\cline { 1 - 2 } hlyQR: 5'- ATCCGCGTGTTTCTTTTCGA -3' & & \\
\hline hlyQP: 5'- FAM - CGCCTGCAAGTCCTAAGACGCCA -TAMRA -3' & & \\
\hline
\end{tabular}




\section{$10^{0} 10^{-1} 10^{-2} 10^{-3} \quad 10^{-4} \quad 10^{-5} \quad 10^{-6} \quad 10^{-7} \quad 10^{-8} \quad 10^{-9}$}

Figure 1. Agarose gel electrophoresis of decimal dilutions: MassRulerTM DNA Ladder, $10^{0}-10^{-9}$ - serial dilutions of L. monocytogenes 4b ATCC 19111.

Slika 1. Rezultati elektroforeze PCR proizvoda: Marker - MassRulerTM DNA Ladder, $10^{0}-10^{-9}$ - serijska razblaženja referentnog soja L. monocytogenes 4b ATCC 19111.

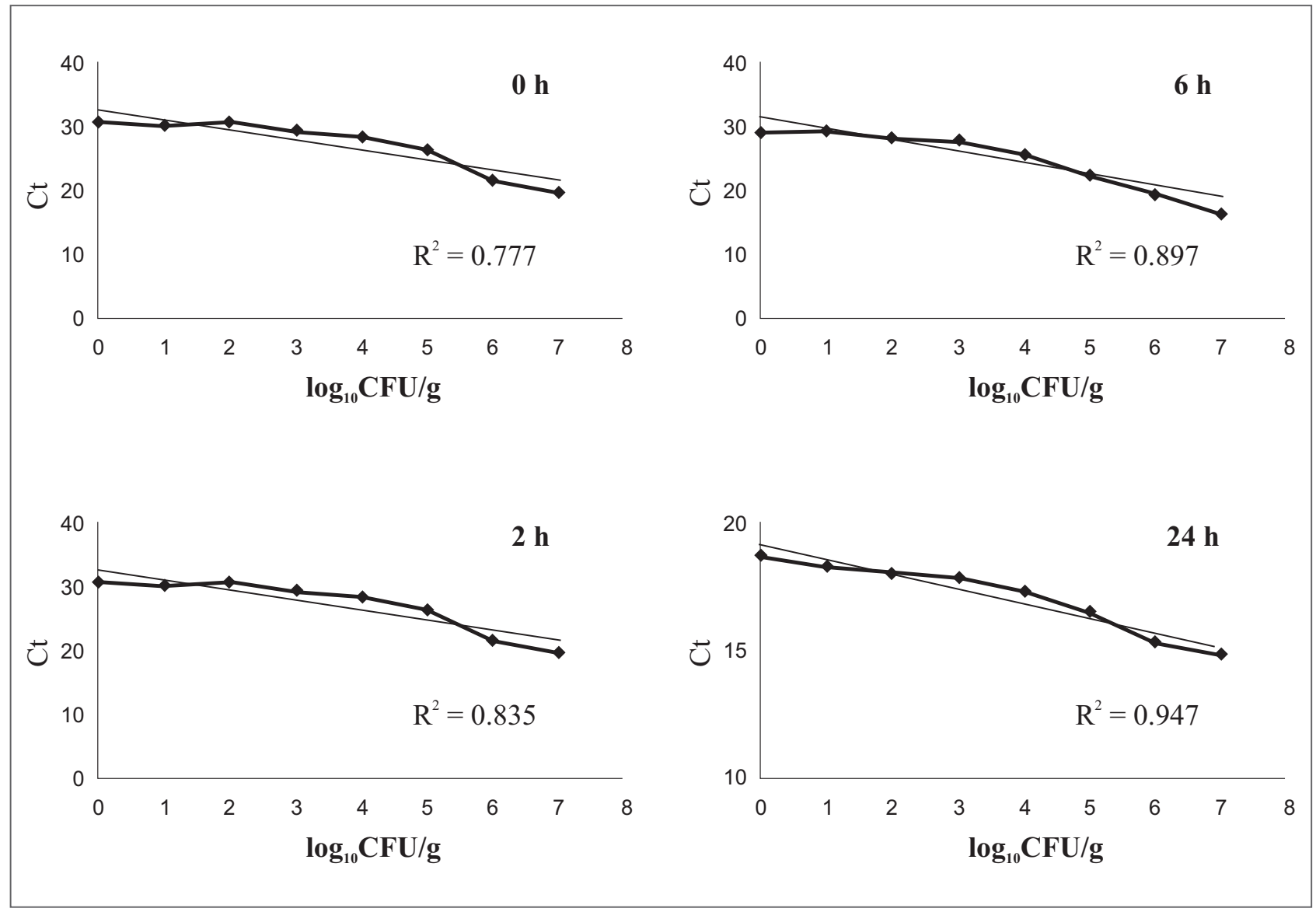

Figure 2. DNA standard curve of L. monocytogenes cell dilutions in fermented sausages after $0,2,6$ and $24 \mathrm{~h}$ of incubation.

Slika 2. Standardna prava DNK serijskih razblaženja L. monocytogenes u fermentisanim kobasicama nakon $0,2,6$ i 24 h inkubacije. 


\section{Real Time PCR conditions}

Real Time PCR was performed in a final volume of $25 \mu \mathrm{L}$ containing Maxima ${ }^{\circledR}$ Probe / Rox qPCR Master Mix (Maxima ${ }^{\circledR}$ Hot Start DNK polymerase, Maxima ${ }^{\circledR}$ qPCR buffer, dNTPs, ROX passive reference dye), (Fermentas, UAB, Lithuania), $0.3 \mu \mathrm{M}$ of each primer (hlyQF, hlyQR), $0.2 \mu \mathrm{M}$ of probe (hlyQP) and 0.1-1 $\mu$ g of DNA template. Samples were amplified in a Stratagene Mx3005P QPCR System (Agilent Technologies, USA), for $10 \mathrm{~min}$ at $95^{\circ} \mathrm{C}, 50$ cycles of $15 \mathrm{~s}$ at $95^{\circ} \mathrm{C}$, and $1 \mathrm{~min}$ at $63^{\circ} \mathrm{C}$.

List of primers and the probe used in this study are given in Table 1.

\section{Results and discussion}

\section{Assay design}

The assay was designed to identify L. monocytogenes from dry fermented sausages with a set of Real-Time PCR primers used to amplify hly $A$ target gene with expected $64 \mathrm{bp}$ amplicon. Two commercially available methods for DNA extraction from dry fermented sausages were evaluated: one convenient format method using silica - membrane spin columns, and the other one using PrepMan ${ }^{\circledR}$ Ultra Sample Preparation Reagent, homogenous solution for lysis. Both methods were simple, fast, easy and effective for the extraction of DNA, yielding similar amounts of bacterial DNA. The PrepMan ${ }^{\circledR}$ Ultra Sample Preparation Reagent, low cost heat treatment-based method, proved to be faster and easier to implement for the extraction of DNA from artificially inoculated samples.

\section{Validation with standard strains}

The assay was initially validated with standard strain of L. monocytogenes ATCC 19111. Amplification patterns of respective 10-fold dilutions are presented in Figure 1. PCR fragments were analysed on gel electrophoresis carried out by applying 10 $\mu \mathrm{L}$ of sample to $1 \%$ (wt/vol) agarose gels. A molecular weight marker DNA Ladder was analysed along with samples. Gels were electrophoresed in a $1 \mathrm{x}$ TBE buffer (10 x TBE: $89 \mathrm{mM}$ Tris, $89 \mathrm{mM}$ boric acid, $2 \mathrm{mM}$ EDTA), (Fermentas), at a constant voltage of $80 \mathrm{~V}$, for $1 \mathrm{~h}$, and visualized by CCD camera Bio Doc Analyze Darkhood (Biometra, Gottingen, Germany).

Moreover, when DNA from non-Listeria strains, such as Campylobacter jejuni, Escherichia coli O157:H7, Proteus mirabilis, Proteus vulgaris, Yersinia enterocolitica, Bacillus cereus, Bacillus subtilis, Enterococcus faecalis, Staphylococcus aureus and Lactobacillus plantarum, was used in the Real Time PCR, no amplicon of any size was obtained. Therefore, using primers and probe directly on DNA extracted from microbial mixtures containing L. monocytogenes facilitates specific detection of Listeria by Real Time PCR amplification.

\section{Detection limit of Real - Time PCR assay for $L$. monocytogenes}

Different pre-enrichment incubation times $(0 \mathrm{~h}$, $2 \mathrm{~h}, 6 \mathrm{~h}$, and $24 \mathrm{~h}$ ) affecting sensitivity of the Real Time PCR method for detection $L$. monocytogenes were investigated on artificially inoculated dry fermented sausages. Two and six hours of pre-enrichment incubation were selected having in mind that 2 and $6 \mathrm{~h}$ are the incubation times that would allow the analysis to be completed on the same working day. Dry fermented sausages were inoculated with an overnight culture of strain Listeria monocytogenes ATCC 19111, covering the range from 1 to $10^{7} \mathrm{CFU} \mathrm{mL}-1$ (determined by plate count on BHA). The method was based on the amplification of the hly A gene using hlyQF / R primers, and hlyQP probeas indicated above. Oligonucleotide primers targeted to the L. monocytogenes hlyA gene were highly species specific, and provided means for easily differentiating L. monocytogenes from other hemolytic species of Listeria (Deneer and Boychuk, 1991).

Signals produced (threshold cycle, Ct) by the serial dilutions of L. monocytogenes were plotted against the $\log _{10} \mathrm{CFU}$ per gram of inoculated sausage, and the standard curves were constructed (Figure 2). The results obtained in the direct RealTime PCR reaction $(0 \mathrm{~h})$, without incubation, indicated that it could not be quantified less than $10^{4}$ $\mathrm{CFU} / \mathrm{g}$. The highest sensitivity level achieved by direct detection was $10^{2} \mathrm{CFU} / \mathrm{mL}$, but it was not reproducible (Aznar and Alarcón, 2003).

The correlation coefficient $\left(\mathrm{R}^{2}\right)$ of $\log _{10} \mathrm{CFU} / \mathrm{Ct}$ value increased over time. The highest correlation coefficient $\left(\mathrm{R}^{2}>0.930\right)$, and the best sensitivity of Real Time PCR method were achieved after $24 \mathrm{~h}$ incubation, detecting less than $10 \mathrm{CFU} / \mathrm{g}$. This is in concordance with the limit of detection reported by Aznar and Alarcón, 1 CFU/mL (2003). The mentioned authors demonstrated that an enrichment step is necessary to detect $L$. monocytogenes and to get reproducible results as well. Pre enrichment guaranties the presence of viable cells in the sample, so that helps avoiding false positive results. They underlined that for longer incubation time the volume of sample has to be $1 \mathrm{~mL}$, and that the DNA purification improves sensitivity of the PCR method. 
The direct detection of $L$. monocytogenes in food is associated with problems such as inhibition of PCR by food components and amplification of DNA from dead L. monocytogenes cells. To solve these problems several reports dealing with enrichment of food sample prior to PCR detection of $L$. monocytogenes have been published (Bansal et al., 1996; Manzano et al., 1997; Agersborg et al., 1997; O'Connor et al., 2000). Finally, conventional microbiological techniques for detection of pathogens use suitable media necessary for the pre enrichment and enrichment, pathogen isolation on selective media, as well as their confirmation by determination of their morphological features, and by employment of biochemical and/or serological tests (Stjepanovic et al., 2007). The time necessary for the final identification and determination of antimicrobial susceptibility is generally 1 to 3 days (Tang et al, 1998), but the obtained results may be false. In contrast, the PCR assay, including DNA extraction, PCR amplification and data analysis, can be completed in less than $8 \mathrm{~h}$.

\section{References}

Agersborg A., Dahl R., Martinez I., 1997. Sample preparation and DNA extraction procedures for polymerase chain reaction identification of L. monocytogenes in seafood. International Journal of Food Microbiology 35, 275-280.

Aznar R., Alarcón B., 2003. PCR detection of Listeria monocytogenes: a study of multiple factors affecting sensitivity. Journal of Applied Microbiology 95, 958-966.

Bansal N. S., McDonell F. H. Y., Smith A., Arnold G., Ibrahim G. F., 1996. Multiplex PCR assay for the routine detection of Listeria in food. International Journal of Food Microbiology 33, 293-300.

Berrada H., Soriano J. M., Pico Y., Manes J., 2006. Quantification of Listeria monocytogenes in salads by real time quantitative PCR. International Journal of Food Microbiology 107, 202-206.

Cocolin L., Rantsiou K., Iacumin L., Cantoni C., Comi G., 2002. Direct identification in food samples ofListeria spp. and Listeria monocytogenes by molecular methods. Applied and Environmental Microbiology, 68, 6273-6282.

D'Aoust J. Y., 1992. Commercial diagnostic kits for the detection of foodborne Salmonella. In: Congress Report Salmonella and salmonellosis, Ploufragan, France 9-19.

Deneer H. G., Boychuk I., 1991. Species specific detection of Listeria monocytogenes by DNA amplification. Applied and Environmental Microbiology 57, $606-609$.

ISO 11290-2, 1998. Microbiology of food and animal feed Horizontal method for the detection and enumeration of Listeria monocytogenes and other Listeria species - Part 2: Enumeration method.

Kathariou S., 2002. Listeria monocytogenes virulence and pathogenicity, a food safety perspective. Journal of Food Protection 65, 1811-1829.

\section{Conclusion}

The proposed Real Time PCR method for detection of L. monocytogenes in dry fermented sausages is specific, non-tedious, and it is simpler and quicker than the standard detection procedure according to the standard ISO method. Also, the application of PCR-based methods is closely linked to the selection of suitable methods for DNA extraction. Namely, the PrepMan ${ }^{\circledR}$ Ultra Sample Preparation Reagent proved to be faster and easier to implement for the extraction of DNA from artificially inoculated samples.

The obtained results indicate that the incubation time has influence on the sensitivity of the Real Time PCR detection method. The best results were obtained after $24 \mathrm{~h}$ of pre-enrichment, with primers and probe complementary to the listeriolysin gene, when it was possible to detect less than $10 \mathrm{CFU} / \mathrm{g} L$. monocytogenes. This assay can be adopted by small public health and food testing laboratories, and food industries, which cannot afford expensive methods and equipment.

Kaur S., Malik S. V. S., Vaidya V. M., Barbuddhe S. B., 2007. Listeria monocytogenes in spontaneous abortions in humans and its detection by multiplex PCR. Journal of Applied Microbiology 103, 1889-1896.

Lakicevic B., Stjepanovic, A., Tolinacki M., Golic N., Topisirovic Lj., 2011. Improved sensitivity and reproducibility of the PCR method for detection of Listeria spp. and L. monocytogenes in milk. Acta Veterinaria 61, 239-245.

Manzano M., Cocolin L., Ferroni P., Cantoni C., Comi G., 1997. A simple and fast PCR protocol to detect L. monocytogenes from meat. Journal of the Science of Food and Agriculture 74, 25-30.

McLauchlin J., Mitchell R. T., Smerdon W. J., Jewell K., 2004. Listeria monocytogenes and listeriosis: a review of hazard characterization for use in microbiological risk assessment of foods. International Journal of Food Microbiology, 92, 15-33.

McLaughlin J., 1997. Animal and human listeriosis: a shared problem?, Veterinary Journal, 153, 3-5.

O'Connor L., Joy J., Kane M., Maher M., 2000. Rapid polymerase chain reaction/DNA probe membrane-based assay for the detection of Listeria and Listeria monocytogenes in food. Journal of Food Protection, 63, 337-342.

Pan Y., Breidt Jr. F., Kathariou S., 2006. Resistance of Listeria monocytogenes biofilms to sanitizing agents in a simulated food processing environment. Applied and Environmental Microbiology, 72, 7711-7717.

Ryser E. T., 1999. Foodborne listeriosis. In: Ryser, E.T., Marth, E.H. (Eds.), Listeria, listeriosis, and food safety, 2nd ed. Marcel Dekker Inc., New York, NY, 299-358.

Schlech W. F., 2000. Foodborne listeriosis, Clin Infect Dis, 31, $770-7755$. 
Schuchat A., Swaminathan, B., Broome, C. V., 1991. Epidemiology of human listeriosis. Clinical Microbiology Reviews, 4, 169-183.

Shen Y., Liu Y., Zhang Y., Cripe J., Conway W., Meng J., Hall G., Bhagwat A. A., 2006. Isolation and characterization of Listeria monocytogenes isolates from ready-toeat foods in Florida. Applied Environmental Microbiology $72,5073-5076$.
Stjepanović A., Marković B., Vesković-Moračanin S., 2007. Molekularno-biološke metode u mikrobiološkoj kontroli mesa i proizvoda od mesa. Tehnologija mesa 48, 123-130.

Tang Y. W., Ellis N. M, Hopkins M. K., Smith D. H, Dodge D. E., Persing D. H., 1998. Comparison of phenotypic techniques for identification of unusual aerobic pathogenic gram-negative bacilli. Journal of Clinical Microbiology, 36, 3674-3679.

\section{Taq Man Real Time PCR detekcija Listeria monocytogenes: uticaj perioda inkubacije na osetljivost metode kod eksperimentalno kontaminiranih suvih fermentisanih kobasica} Lakićević Brankica, Velebit Branko, Janković Vesna, Spirić Danka, Baltić Tatjana, Mitrović Radmila,
Babić Jelena

R e z i m e: Listeria monocytogenes, prouzrokovač listerioze kod ljudi i životinja, je fakultativni Gram pozitivni, katalaza pozitivni intraćelijski mikroorganizam, široko rasprostranjen u različitim staništima. U cilju izolacije $i$ detekcije L. monocytogenes $u$ uzorcima hrane, koriste se klasične mikrobiološke tehnike i moderne molekularnobiološke metode. Cilj ovog rada je bio da se ispita uticaj perioda inkubacije na osetljivost TaqMan Real - Time PCR metode. U tu svrhu, suve fermentisane kobasice su eksperimentalno kontaminirane serijskim razblaženjima L. monocytogenes ATCC 19111. Dobijeni rezultati su pokazali da je period inkubacije važan faktor koji utiče na osetljivost Real-Time PCR metode. Najbolji rezultati su dobijeni nakon 24 h predobogaćenja, korišćenjem prajmera i probe komplementarnih listeriozin (hlyA) genu, kad je moguće detektovati manje od $10 \mathrm{CFU} / \mathrm{g}$.

Ključne reči: detekcija, L. monocytogenes, PCR u realnom vremenu, osetlivost, izolacija DNK.

Rad primljen: 9.12.2014.

Rad ispravljen: 14.03.2014. 